\title{
THE RELATIONSHIP BETWEEN SUSTAINABILITY AND CONTEMPORARY FASHION DESIGN: AN ANALYSIS OF THE SEGMENT JEANSWEAR
}

Mónica Moura e Mariana Dias de Almeida

monicamoura.design@gmail.com, mari.ddalmeida@gmail.com

Faculdade de Arquitetura, Artes e Comunicação, Universidade Estadual Paulista (UNESP)

\begin{abstract}
Fashion is one of the reflexes that best expresses the dynamics of contemporary, and sustainability is one of the questioner agents of the concept and approach of fashion and fashion design, this way, the purpose of this paper is to present a critical analysis of the relationship between fashion and sustainability, with the aim of comparing and verifying the discourses of advocated by jeanswear segment companies and the development of its garments, called "sustainable". The reasoning begins from literature review of these areas added to field research with structured interviews, application of questionnaires and later analysis of companies.
\end{abstract}

KEYWORDS

Contemporary Fashion; sustainability; jeanswear

\section{INTRODUCTION}

Fashion is creation, expression, language, identity; it promotes identity and streamlines its artistic and cultural production from an economic system that continuously generates objects of consumption for different segments of national and international market. Fashion is in tune and, often, speeds up the time in which we live. "A good example of this particular experience of time that what we call contemporary is fashion" (Agamben: 2009: 66)'

Fashion goes through many temporal changes, builds new meanings and satisfies social, aesthetic and cultural demands (Simmel, 1971). New shapes that fashion has acquired in the last twenty years directly influenced the change of values, and some of these values has demonstrated and acted as questioner agents, such as sustainability.

The advertising appeal involving sustainable fashion can be observed in publicity campaigns of new collections, in which the direction is for the final consumer and the main intention is to demonstrate that the companies are concerned about sustainability. This attitude is one of the most important aspects nowadays to conquer the audience.

As contemporary fashion relates with sustainability and as it questions values acquired by fashion, they are necessary reflection to understand why it is indispensable to discuss this theme. Therefore, this paper raises the discussion if sustainable fashion is actually sustainable, focusing on jeanswear segment.

'All the quotations in this paper were translated by us. 


\section{CONTEMPORARY FASHION}

The term contemporary can have a simple definition, common to be said, because this word came to be used for almost everything nowadays. However, the concept of contemporary lacks a better contextualization. For that, some author have been consulted, such as Lipovetsky (2004), Charles (2004), Agamben (2009), Caldas (2004) and Moura (2008a, 2008b), that present findings that contemporary is much more than a generic term. Agamben (2009) states that contemporary is something that can be found in the same time we witness it. But this is not enough, it is necessary to know how to move from the present time to be positioned in a different angle and capture the essence of its time.

Moura (2008) states that when there is a detachment from the present it must relate with historic context, analyzing the questions and object of study with recent events, this way, the vision and analysis field can be amplified, noticing how to better observe contemporary and contemporaneity. Thus, it is concluded that contemporary is everything that detaches from present conjunctures and interrelates with close past and history constructing the present and pointing the near future. Contemporary is deeply related with is own time.

Lipovetsky and Charles (2004) when observing contemporaneity named it as hypermodern. They implanted the suffix hyper to modernity, as it expresses best the events that have been marking this period. This way, they translate the feeling that amplitude of things and exacerbated excess lead to "hyper" which is driven by capitalism and consumerism craving, demonstrations of the characteristics of current times that become to denominate this moment: hypermarkets, hyperways of information, hyperconsumerism. They still demonstrate that "unrestrained modernization, made of proliferative commodification, economic deregulation, technical-scientific impetus, whose effects are so laden with dangers as many as promises" (Lipovetsky \& Charles, 2004: 53).

The compression of time is also a contemporary factor, the feeling of outdated emerges at any instant, as the sensation that one is below other and things, progressing less than other, these are frequent unrests in consumption and communication, that has as a result more product and news that continuously reach individuals and attract before illusion, so the feeling of exclusion will not have space in people's life.

Fashion is one of the symptoms of contemporaneity, for its characteristics such as time compression and excess reflected in consumption. Agamben (2009) considers fashion as an experience of contemporary moment. On the other hand, to affirm this relationship of fashion versus time, Caldas states that "The continuous change, the permanent manufacture of new and the acceleration of consumption migrated from fashion to high technology industry" (2004: 82). However, when observing in more detail this situation proposed by Caldas, we can notice it was fashion industry that led different market segments to acquire this behavior, the consumerist urge impelled companies and market, whether of technology, furniture, among others, which, in turn, changed the behavior of their segments doubled trends and fashion dynamics.

The mishap between fashion and time promoted the accelerated development of products, specially clothing. Every year two, four or more collections are launched. Time 
reigns in deadlines for garments manufacture and also in limits for trends and in the lack of judgment capacity. Thereby, as Agamben states:

What defines fashion is that it introduces a peculiar discontinuity in time, dividing it according to its actuality or non actuality, its state of not-be-infashion-anymore [...] The time of fashion is constitutively advanced for itself and that is exactly why it is also always late, always has the form of an elusive threshold between a "not yet" and a "no more " (2009: 66-67)

This feeling of outdated, of carrying something that clashes from the moment and that increases the desire of consume, generates a feeling, also classified as perceptive obsolesce. According to fashion trends, obsolescence must surpass the other characteristics, making industries and consumers search for the new in a continuous cycle of generating demand, production, consumption and discard.

Moreover, this dynamic leads to the awareness of many individuals and groups of people creating change in values regarding fashion as a whole and to fashion design, especially, that in the contemporary joins sustainability. Although many agents, creators and designers still point these relationships with pessimism. For example, Oskar Metsavaht, owner of Osklen (brand that aims to develop garments with sustainable statement), points out in an interview with journalist Ricardo Oliveros (2012), that sustainable fashion can only be possible in the future, in a 100 years term, because he believes that many complex changes must happen. From the suppliers of raw materials to the final outcome of the garment.

On the other hand, the clothing sector has been one that most innovates concerning sustainability, even that this rapid assimilation needs better verification and evidences, since one can not forget that for fashion the best time is immediate.

\section{RELATIONSHIP BETWEEN FASHION AND SUSTAINABILITY}

Fashion is part of hypermodern context and carries contemporary characteristics. However, it is believed that the union of fields such as fashion and sustainability can potentially contribute in a significative way in favor of a new reality. Even against unfavorable points for sustainability, already mentioned before, it is believed that there is the possibility of the reversal of a number of principles and values that appear sediment. Evidently, there are companies that try to stay only in the superficiality, but these ones will hardly remain in market for too long with this proposal.

Given this perspective, sustainability, inside fashion, appears as a new posture apparent in the process of products development. Researchers such as Proctor and Dougherty (2005) deal with this subject as something that will continue and evolve through time, being introduced in human habits and industry transformation.

Some elements that fashion owns provide it with untenable character, that, as shown previously, are qualities of contemporary that were incorporated to the project of its products, inherent needs that overlapped the paradigm that is presented to us: "Fashion, not only in dressing, but in objects of consumption in general, has always found fertile ground in capitalism and now it looks for an alternative, it seeks for new appeals for consumption" (De Carli, 2010: 40). 
From this point of view it is stated that clothing was the first field to incorporate the process of temporality, rapid oscillation, fact that can be noticed in other sector since the end of the 2oth century to the present, as furniture, language, decorative objects, among others (Lipovetsky, 1989).

Baxter (2011) states that the replacement of mature products for new ones will provide a breath in consumption. From this statement about fashion design derives an important concern: the wastes. How will be intended the hundreds of clothes that are withdrawn from circulation, for not being appreciated for consumption, because of perceptive obsolescence? It is known that many will argue that such garments are intended for donation to charity, demonstrating the humanitarian side of the issue, but still it does not answer all sustainable issues, because these same garments will be discarded later. There is recycling, which is not a very recurrent practice today because some consider it very laborious and costly.

Examples such as these denote how fashion design holds challenges to be overcome, a design that changes in a practical way, going beyond a discourse. Sustainability is a critic to fashion, because it "challenges fashion in its details (fiber and processes) and also regarding the whole (economic model, goals, rules, systems of beliefs and values)" (Fletcher \& Grose, 2011: 8).

In a first analysis, it is noticed contradictory elements to fashion dynamics, as state Parode et al.:

in different fashion stances, we can identify contradictory movements, at times consumption promoters, at others values and symbolic goods adjusters in a perspective of economy and ecologic consciousness. (2010: 69)

It can be stated, therefore, that sustainability is one of the biggest contemporary challenges for fashion, because, with all the demands for a product become considered sustainable, fashions finds obstacles to be overcome.

Thereby, in the following paragraphs, it will be discussed points in which fashion still finds elements contrary to sustainability. Some occur through sequential implications, they are events so present in contemporary fashion that it can be hardly unlinked from them. They are realities that became to be assimilated in fashion system, such as ephemerality, perceptive obsolescence, consumerism, defragmented industry, use of organic raw material as a way of making the product become sustainable.

\section{VIABILITY OF SUSTAINABILITY IN FASHION}

Some points can already be raised so it can be enabled sustainability in fashion with new innovative scenarios. In Brazil, it is not possible yet to affirm for sure about the insertion of some of these elements, because the country is in a position that entails harmful effects, as in the case of the system of labor similar to slavery; in the consumerism mode that have been feeding the rise of classes $C$ and $D$, as in the case of installment sales of large stories and in the reduction of taxes for acquisition of automobiles. 
Thus, the comprehension of sustainable fashion must come out from superficiality and be based in fundaments with more consistency and clarity. Therefore, this theme has been widely discussed in scientific congresses, academic researches and NGOs, generating a considerable volume of scientific researches and reports that have denoted the concern with investigation proposals and sought solutions for sustainable fashion. Following, we present a table (Table 1$)^{2}$ with some national academic actions that propose changes in fashion for the discussion and implantation of sustainability.

\begin{tabular}{|c|c|c|}
\hline \multicolumn{3}{|c|}{ ACADEMIC INSTITUTIONS } \\
\hline NOMENCLATURE & DEFINITION & PURPOSES \\
\hline Eco-fashion & $\begin{array}{l}\text { UDESC (Santa Catarina State Univer- } \\
\text { sity) project, that proposes to address } \\
\text { social and environmental issues. }\end{array}$ & $\begin{array}{l}\text { Disseminate the concept of sustai- } \\
\text { nability, interaction academy and } \\
\text { community, adequation of new } \\
\text { fashion products with low impact. }\end{array}$ \\
\hline $\begin{array}{l}\text { Fashion, sustainability and inclu- } \\
\text { sion: straws that weave stories }\end{array}$ & $\begin{array}{l}\text { Project developed at UEL(Londrina - PR } \\
\text { State University), through workshops } \\
\text { that create garments with textile residue. }\end{array}$ & $\begin{array}{l}\text { Create products with university stu- } \\
\text { dents of fashion design course and } \\
\text { the local community, demonstrating } \\
\text { the possibilities with residues. }\end{array}$ \\
\hline Fashion conference & $\begin{array}{l}\text { International scientific congress } \\
\text { about fashion design, that occurs } \\
\text { every year. With individual sessions } \\
\text { in Work Groups, there is one speci- } \\
\text { fic for sustainability discussion. }\end{array}$ & $\begin{array}{l}\text { Promote sustainability as a new } \\
\text { parameter for fashion, publishing the } \\
\text { researches involved in academic field. }\end{array}$ \\
\hline $\begin{array}{l}\text { Brazilian Congress of Research } \\
\text { and Development in Design } \\
\text { - P\&D Design }\end{array}$ & $\begin{array}{l}\text { National scientific congress about } \\
\text { design and the biggest in Latin America } \\
\text { in the field of design, it is a biannual } \\
\text { event for the discussion of research } \\
\text { and design education in Brazil. }\end{array}$ & $\begin{array}{l}\text { This scientific event has been pre- } \\
\text { sented as an important forum for the } \\
\text { dissemination and discussion relevant } \\
\text { to the advancement of knowledge } \\
\text { resulting from basic and applied } \\
\text { research in design, being one of its } \\
\text { themes design and sustainability. }\end{array}$ \\
\hline $\begin{array}{l}\text { International Symposium } \\
\text { on Sustainable Design } \\
\text { SBDS/ ISSD }\end{array}$ & $\begin{array}{l}\text { National and international scien- } \\
\text { tific event, biannual, which main } \\
\text { focus and theme is the issue of } \\
\text { sustainability in their various fiel- } \\
\text { ds, aspects and relationships. }\end{array}$ & $\begin{array}{l}\text { Promote and disseminate sustai- } \\
\text { nability for many different areas } \\
\text { and segments, disseminating the } \\
\text { research developed in national and } \\
\text { international academic field. }\end{array}$ \\
\hline
\end{tabular}

Table 1: Some action for sustainable concepts dissemination

Sources: Berlim, 2012; Moura, 2013

With academy helping promoting new viability of sustainable fashion in Brazil, it is possible to articulate in a long term new changes in development, manufacture and even in the individual and collective consumption behavior.

Vezzoli presents some proposals that might "change social perception of the quality of what is being offered, the appreciation of possession of always new products [...] the satisfaction understood as access to a certain benefit or good" (2008: 201). The first proposal would be exchange and maintenance centers; the second consists in rental and treatment of clothes so it is possible to preserve longer the efficiency of the garment, optimizing it; the third proposal is customizing, co-creation of the user generating values related to the garment or object that avoid unnecessary discards and are kept to the

${ }^{2}$ Translated by us. 
individual; and the fourth proposal, more durability, trough tailored clothing and maintenance of them.

Other researchers, such as Parode et al. (2010), believe that sustainability can be possible with the help of technology, because it can be materialized trough it, as fabrics, that in some cases use biomimetic, that uses nature's behaviors and aspects to mimic its systems and apply them to products in shape or function.

Fletcher and Grose (2011) present the idea that innovation can represent an opportunity so new practices would modify systems, ways of obtaining some products and new values. Having it as a premise, the authors classified some innovative links gifted with ways for planning the development of products, which are: adaptability (more versatile garments, flexibility), optimized life cycle, low impact in finishing, share, the importance of the use of raw material or artisanal work or vernacular and the decrease of speed at which the products are produced.

These are points of view of some authors/researchers, but it might arise other aspects to be implanted, adapting these models to where and for which it is projecting. It is believed that there is not and will never be a perfect recipe or formula, so it can be chosen the best alternatives for each type of product that adapts to the system that will be available.

Lipovetsky (1989) points out the need of overcoming the existent paradigms seeking the recycling of fashion, from the belief that this new attitude does not mean the end of new possible ideologies, yet changes in its trajectory. In this sense, Thierry Kazazian suggests:

[...] the progressive passage from a consumption society to a so called usage society [...]. Objects of everyday life must change radically. It is not about producing less, but differently. (2005: 10)

A sustainable product has the intention to modify some patterns culturally impregnated, directed to modify a sociocultural reality which is found unsustainable, the product acting in way that the individuals would assimilate and accept questions that favor the environment (Vezzoli \& Manzini, 2008).

The adoption of the term sustainable by fashion implicates in changing paradigms that, by times, have characterized it with ephemerality, rapidity and agility. Parameters that permeate the process of product development, guiding designers who sometimes seek to respond to the needs of their target audience, developing products that meet the most immediate and implicit desires of their consumer, instigating them to consume at every launch with new garments.

The orientation so the efficiency of fashion products is really sustainable is to promote academic researches and awareness in companies. Parode et al. (2010) suggest a new patter from the change of posture and adoption of the preoccupation with environment and society. A posture that fashion, in the last years, have sought to adopt.

Fashion, it can be said, is one of the main agents of creating this new pattern, which is now followed by companies from all sectors of the economy, but it brings up a huge disparate. As discussed before, fashion is stimulatory 
of ephemerality, signification of objects and rapid change of these signs to keep up in society. Moreover, fashion is seeking more sustainable and eco responsible solutions to produce its products, which in practice means sort of an economy of signs (Parode et al., 2010: 72).

Therefore, a way to develop fashion products, which will begin to be increasingly measured by actions that interfere in natural systems arises, whose focus is the impact that clothes provoke, either by its manufacturing process or by the simple everyday use. The changing in fashion paradigms must happen in the whole, in other words, small changes, such as the alteration of raw material, which the product is made, are not enough to affirm it as sustainable, there is the need of changes in the projetual phase, the manufacture process, the lifetime of the product and designer awareness, for being the one who thinks and conceives the project, systems and products.

\section{JEANSWEAR SEGMENT}

Jeans are used in the manufacture of garments and gain prominence in the confection of trousers worn by many individuals, of different ages and social conditions. Jeanswear is a part of fashion products that have great complexity because it requires an extensive and articulated network of manufacturing. (Mendes \& Lima, 2012)

Brazil has important industrial parks for clothing, which concentrates most of jeans manufacturing, as the rural region of Pernambuco, the city of Toritama; within the state of Paraná, the cities of Cianorte, Londrina and Maringá; the state of São Paulo, the metropolitan areas near Campinas and the city of São Paulo.

The city of Toritama, as an example of how significant the jeanswear market is, is part of the Polo do Agreste that has 2,500 factories and produces the equivalent of $16 \%$ of national production. The city, which is considered the "capital of jeans", had an incensement in population of $63,4 \%$ in ten years, motivated by employment in jeans industries that employ part of the local population and neighboring municipalities. (Tavares \& Arnt, 2011).

These and other manufacturing parks throughout Brazil total the production that worth $\$ 8$ billion $\left(\mathrm{ABIT}^{3}, 2011\right)$, the country is still located in the fifth position of largest textile industry in the world, the second largest producer in denim.

So, it is noticed how important is for clothing industry the production of jeans garments, because it strengthens the internal product and marketing is highlighted, since $46 \%$ of Brazilian population wear jeans every day and gets to buy, on average, seven pieces a year (ABIT, 2013).

Jeanswear productions are continually increasing, because in 2012 the segment had a growth of $3.5 \%$ in volume of garments and $7.9 \%$ in parts sales, totaling U.S. $\$ 7.3$ billion (ABIT, 2013). Judging by the economic factor, jeans offer to Brazil a very significant value regarding the textile material, denim, because, according to Richard Weiss, president of Tavex (denim manufacturer), the country still has a prominent position and leadership in the sector, but when dealing with manufactured garments, it suffers with

3 Brazilian Association of Textile and Clothing Industry. 
the increasing influence of the Asian market, creating negative impacts across the entire chain (ABIT, 2013).

For all economic and marketing factors that point the relevance of the jeanswear segment that, as well as other segments of clothing products, has a number of negative aspects related to the environmental impact, jeans is highlighted as a complex niche and loaded with factors that question the possibilities of implementation of sustainability. In the following topic it will be discussed some opposition regarding jeans and sustainability, questioning and reflecting whether it is possible that this union will happen.

\section{JEANS AND SUSTAINABILITY}

Jeans is a garment that has many impasses to make sustainability possible, because in addition to all paradigms of fashion (already seen in previous chapters), the burden of negative environmental and social impacts can be considered high, resulting from various factors, as in the case of production, origin of raw materials and services, which are of various and distant sources, such as Thorpe presents:

For example, a pair of jeans draws together materials from all over the world. Synthetic indigo comes from Germany, pumice for stonewashing comes from Turkey. Cotton for denim comes from Benin and cotton pocketing comes from Pakistan. Polyester fiber for thread comes from Japan and copper for fasteners comes from Namibia and Australia. Bound together in a pair of jeans, these diverse materials are deposited in European stores. The jeans represent the long process in which raw materials [cotton, copper, polyester] lose their original structure and concentration, their potential, and get spread in less useful forms around the globe. Our current human systems offer no practical way to structure and concentrate the materials from billions of pair of jeans (2007: 41). ${ }^{4}$

The unsustainability of jeanswear industry goes through many places, due to the various industries that connect to form a chain, in order to build a garment, with the manufacturing of various materials in different locations, which demonstrates how much jeans is globalized and it is needed to know the source that produced certain material and whether it meets sustainability.

Jeanswear segment has two points to be solved, which are: laundry and unethical industry. Therefore, it is needed detail these issues, to determine the depth of the impact of this segment.

Laundry is one of the most important meliorations in jeanswear industry, it is responsible for the transformation in the textile fabric, adding finishing, staining and comfort, because the raw denim is starched during the manufacturing of the garment, only in the laundry, through washes with chemical, the product becomes suitable for use.

\footnotetext{
${ }_{4}$ Original quotation.
} 
To give the trousers the outworn aspect, chemical substances are used, as ammonia and caustic soda, which, besides harmful to health, are highly polluting. Added to this, there are enormous volume of water and energy spent and tons of $\mathrm{CO}_{2}$ (carbon dioxide) emitted over the product life cycle. (Tavares \& Arnt, 2011)

The use of chemical compounds produces effects that add market value to jeans garments, but these same chemicals harm the environment, which may influence the health of the population surrounding the places where the laundry wastes will be dumped. There are those who make the process reusing the water or make the water return to the environment without impurity residues.

The washing and dyeing of the trousers still require large amounts of water and chemicals, because, as Fletcher and Grose state: "Water is an essential problem for textile fibers and therefore to the fashion industry" (2011:28). About this issue, it should be emphasized that the use of water varies from one piece to another, it is necessary an evaluation and innovation in water use, because if every pair of jeans trousers consumes 20 liters in its manufacture, washing contributes to this aquifer quota of one piece.

Most laundries that have high production factor are in China, India, Tunisia and Brazil, and although there are a large concentration of newspaper reports on the pollution of rivers that reach chaotic levels, leaving them improper, they portray the absence of treatment of water used in washing, generating as visible result the color change of the waters of these rivers, which is changed with the passage of time, depriving the population of its use for subsistence (Exame, 2010).

On this point, it can be illustrated by citing two documentaries that demonstrate how the lack of legislation and industrial neglect make the production of jeans garments, entail a significant impact of context on lakes and rivers. The first is the French documentary Le Tour du Monde d'un Jean, which shows rivers in Tunisia that started having indigo blue color, a country that is a reference for laundering garments coming from Europe. The same happens with rivers from the city of Toritama (PE), as recorded in a report made by Globo TV, streams that have blue color, even with the prosecution having in 2001 , required greater awareness and adequacy of laundries, what is noticed is that there are still companies acting erratically, as may be ascertained in the mentioned report that was aired on national television in August 2012.

It is worth noting that it is not only because rivers and streams appear with bluish color, but this is an indication that the water is sourced from some laundry, when dumped it still contains all the chemicals to dye a jeans garment. This is a conventional scenario for laundries, for there have been others cases before these, as in the city of Tehuacan, Mexico that for years has catered to U.S. companies, such as GAP and Levi's, and it was the city that most produced jeans worldwide, however, due to the constant pollution of rivers, food were contaminated, because the same water that was drained from the laundries served for crops irrigation, which brought national and international loss. (Tavares \& Arnt, 2011).

Fashion is a great business that moves world's financial markets through this multiplicity of countries that are involved in the production chain. Crises and negative impacts 
correlate with local and global economy, for example, what happened to a scenario like Mexico was the transfer of production to other countries, which are not consistent with the implementation of laundries without proper structure.

And, reinforcing with Frings statement (2012), it happens because American textile producers are not concerned with environmental improvements, since the expenses are high, and while environmentally responsible companies pass on their costs for products, increasing values, companies that compete with low prices for not paying to clean up the environment can gain more market share.

The market fails to absorb what a location offers to extract elsewhere, that is due to polluted environments left by industries, they move to places that can provide the infrastructure that meets the needs for its operation, leading to these new territories the possibility of the emergence of problems already presented in previous locations.

This is the case of China that started operating great part of laundries that are responsible for the companies that were previously in Mexico, but there are already signs that there is pollution in Chinese rivers, resulting from water boilers, as in the case of Pearl River in the city of Xintang.

The city of Xintang produces $60 \%$ of jeans trousers in the country (exporting $40 \%$ to United States and Europe), the city is recognized as the "jeans capital of the world." In an analysis made by Greenpeace in the waters of Dong River, there were found metals that are harmful to health, such as copper, cadmium and lead, with levels up to 128 times higher than the acceptable limits (Exame, 2010).

The production of jeans garments grows as the market looks for clothing of this segment, which can be found at affordable prices. To achieve this feat, fashion industry uses cunning methods that meet the ethical concept, which covers issues of labor rights, raw materials produced in accordance with ecological concerns, animal rights and not promoting unhealthy bodies (Matharu, 2011).

In light of the issues raised it is explained another problematic of jeans industry, which is the lack of ethics. It is known that this is not just an isolated case of this segment, but the notoriety it gained in cases of absence of labor rights and possible social negligence have focused on jeans.

Cases analogous to slavery, child labor and lack of compliance with labor laws, China is the largest exporter, employs about 20 million workers, but the lack of labor rights, poor working conditions and low wages reflect questions of how negligent is the fashion industry (Matharu, 2011).

The case of Chinese factories became more evident with the documentary China Blue (2005), which shows the labor exploitation in companies that manufacture jeans, with most workers, mostly women, living on the premises of the factory, because they are migrants from the rural or other remote locations. The reports demonstrate poor conditions, excessive working hours, which is usually 11 hours, but can reach up to 19 hours, because companies are focused on delivering the deadline to ensure that customers, most Europeans and Americans, continue to consume and feel satisfied with what is manufactured. 
Brazil, despite having laws that safeguard rights of workers, does not shy away from scenarios of labor exploitation in the jeanswear segment because, besides having works analogous to slavery, especially with foreign workers, most of them Bolivians who work for hours beyond as provided by law, there are cases of factions ${ }^{5}$ that work in houses and sheds, some without regulation, disadvantaging the workers.

Although some companies receive the title of social responsibility, they may be accessary with inadequate means of work, as with the subcontracting it is possible to have low product prices, arising from low wages, there are companies that keep other accounting books to elude oversight (Fletcher \& Grose, 2011).

The fact that jeans is a democratic garment and have many production functions can cause greater reproof, for a trouser can pass by the hand of 17 people (Tv Asa Branca, 2011), which leads in more production time, implying in a complex garment. The demand for the garments to be manufactured presses workers to develop pieces rapidly to meet a short timeline for the goods to arrive on time at the hands of the consumer.

Therefore, even with the approach of points already seen in the topic Relationships between Fashion and Sustainability, it was important to investigate in jeans particularities, because this segment differs from other garments mass produced, by the diversity of production and garments that are complex in their manufacturing, as, for example, a blazer, because garments as this are not produced in a volume comparable to jeans, and they not persist in the whole year collections. Jeans fits all seasons.

Jeans garments have to overcome fashion adversities and their own method of production to suit the sustainable concept. If sustainability is a fashion questioner, for jeans, beyond questioning, one must propose a reformulation of the entire system of development and manufacturing.

The existence of projects that act on deficiencies, where the raw material is inspected and analyzed, so that starting from the extraction (beginning od the cycle), the project consisted on the same axis; awareness of individuals approaching the usual reality, thereby showing the possibilities of how to reduce harmful impacts.

Proposals for new aspects with inclination to the appeal of awareness are discussed, having the product lifecycle more prominent, however, to complete the product, the entire process must be analyzed and be predominant in the steps of fashion products, in our study case, jeans garments.

\section{Methodology}

The analysis of data obtained from professionals representing the studied companies allows us to develop the questioning and confrontation with the theories from the literature review and with the responses of the interviewees, added to the promotional discourse of companies from different statements contained in the answers for the questionnaires applied.

It is worth emphasizing important points, such as the choices for the interview. In this aspect, there were selected and questioned individuals involved in product development sector. The other selection standard adopted was the fact that the company has

\footnotetext{
${ }^{5}$ Small manufacturers that only produce, and do not develop garments.
} 
developed its promotion and advertising claiming that their products are sustainable, as well as the fact that jeans is the main product of commercialization for these companies.

Thus, the Sacred Heart University Ethics in Research Committee (USC) approved the present study upon the advice of Protocol number 133/11, on August 25, 2011. Subsequently, the questionnaire was applied to interviewees after the presentation and explanation of the research and signing the informed consent form, which makes ethical the procedure and ensures the confidentiality of identifying information.

Thereby, we analyzed the companies who consider themselves sustainable through the products they manufacture and the sustainable aspect that guides consumers to buy the products of this company.

The companies will not be identified by their brand names in order to avoid any predeterminations and preserve the identity of the companies, because the important in this research is to know the actuality of sustainable fashion market.

Three companies were observed and studied, two in the business of garments manufacture and another in the textile segment; this amount is justified by the fact that there is still not many industries in the area of clothing that present themselves as sustainable. And also because many industries that support this speech refused to participate in the research that is now presented in this paper.

The questionnaire consists of questions about the activities of the companies, the notion of knowledge on sustainability, life cycle and product development. The questionnaires were arranged in semi-structured interviews in order that they might be suitable for questions and other relevant data and information from the interviewees and clarify any questions that may arise about the company.

What is sought by the questioning is to determine the depth of knowledge on the subject of this work, how they work with sustainability, knowledge and application of life cycle, the difficulties in developing a product with this specificity and to investigate whether they are sustainable or not, in line with statements made by several authors previously discussed.

\section{RESULTS}

The garment manufacture companies interviewed ( $A$ and $B$ ) are small, operating in the cities of São Paulo $(A)$ and Belo Horizonte $(B)$, respectively. Both produce an average of 40,000 items per year in the casualwear segment. The professionals interviewed have been working for about six years in their respective companies. The interviewee textile industry (C), from the city of Santa Bárbara d'Oeste (SP), is of medium size, with a production of 5 million meters / month. The interviewee works for the company for nine years.

The fact that the interviewees act for a long time in the researched companies secured more credibility to the research, because they hold deep knowledge about the company in which they operate. This way, they could detail the elements and characteristics that surround the development of products and their relationship with sustainability.

In order to confront the first hypothesis of the promotional discourse with the interviews, there will be presented some images and concepts coming from the websites, 
advertising campaigns and social networks that indicate the discourses promoted by these companies. These data were compared with the responses of the interviewees.

Company A presents in its advertising campaign that the brand has started its activities with sustainable order since its genesis, it also indicates the use of organic raw material as fundamental to the development of products, it works with professionals responsible for the product to become possible. At the end of the description of the concept presented on the website (Figure 1), the company claims that it is possible to combine fashion with sustainability.

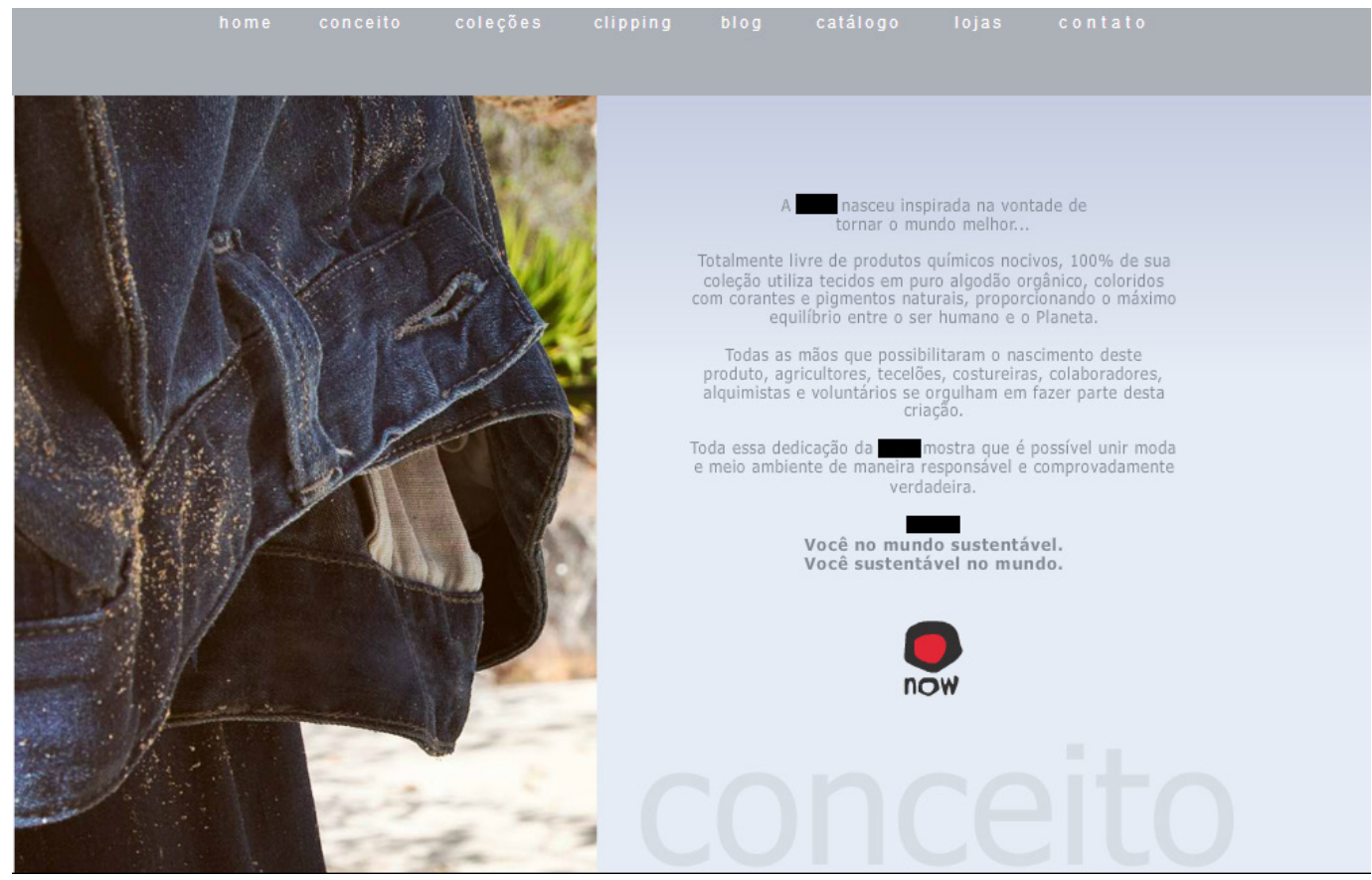

Figure $1^{6}$ : Brand concept

Source: Official brand website. Accessed on: April 14, 2013

The responses obtained by interview and questionnaire lead to observe the confirmation of the statements contained in the website of the brand, as in the case of organic raw material, that the interviewee highlight they are organic, since they produce their own textile raw materials that have the certifier label NOW (Natural organic World), which is a label owned by the company Coexis, a certifier of organic products, located in the city of Barueri (SP).

The company relies on the concept of organic to assert their garments are sustainable, being the basis for monitoring the whole product development. The concern with the health of farmers is another point presented in the video available on YouTube channel,

\footnotetext{
${ }^{6}$ (Omitted for ethical reasons) was born inspired in the idea of making a better world.

Entirely free of harmful chemicals, 100\% of its collection use fabrics in pure organic cotton, colored with natural dyes and pigments, providing the ultimate balance between human being and Earth.

All the hands that made the birth of this product possible, farmers, weavers, seamstresses, employees, alchemists and volunteers are proud of being a part of this creation.

All of this dedication (omitted for ethical reasons) shows that is possible to unite fashion and environment in a responsible and demonstrably true way.

You in a sustainable world. You sustainable in the world.
} 
so the procedure in the origin of the raw material is primordial, the way of cultivation and social responsibility with family farm, point also observed and reported in the interview.

In the video above mentioned the company addresses the knowledge of the product life cycle, however, in interview, we realize the ignorance about this methodology. It seems that the question about the methodology of the life cycle of the product is empiri$\mathrm{cal}$ in monitoring the development and production of the product, or the company leaves no explicit that such methodology is adopted.

Thus, there was no knowledge of any other methodology applied to the design process of the product, the interviewee also states in the questionnaire that designing the whole product chain has a high cost; this response only became known after a brief explanation about the concept of the product life cycle. When asked about how the product is developed, the interviewee states that the primary focus is the raw material, the company cannot be claimed as a sustainable, just for the material with which the product is manufactured.

Company B presents its concepts disclosed in the institutional website, very similar to the discourse of company $A$, especially regarding organic products, but it also indicates the use of recycled material. The point that is worth mentioning is about the social values that appear in projects and ethical action through fair trade (Figure 2).


Figure $2^{7}$ : Concept of brand $B$

Source: Official brand website. Accessed on: April 14, 2013

\footnotetext{
7 Fashion, Sustainability and Ethics

The (Omitted for ethical reasons) was born from the desire to combine these philosophies. Since its foundation, in 2006, the company invests in the development of new techniques and partnerships for the manufacturing of its products. Brazilian culture and nature are inspirations for the conception of unique garments, developed with $100 \%$ natural, organic and recycled fabrics. The company proposes different ways of working, encouraging attitudes that reflect the peaceful integration of man with nature. The company also invests in social projects, and believes in maintaining a fair trade, developed through ethical values and sustainability rules. (Omitted for ethical reasons) is an innovative company which grows in a responsible way and reinvent itself when proposing new ways of thinking and acting.
} 
The professional interviewee from company B states that he knows the sustainable theme and addresses this aspect in similar ways both in the interview as in the company website. The concept and discourse are grounded through then aspect of the company and its projective beliefs, as well as their performance in the market through fair trade and the importance of environmental and social reconciliation.

The same can be seen in the brand page on a social network, how it presents the company to the general public, with its concepts and values, makes clear the products they develop. In the interview, the responsible designer states that has his training focused on the sustainable area acquired in a post-graduation courses in Environmental Management and the importance of addressing sustainability is a matter of survival and quality life assurance to the company and for their customers / clients. He also states that, through social networks, they can measure the level of acceptance of their products and customer understanding regarding products developed by the company and sustainability, which indicates the importance of customer perception for the company in the development of the product, which, in the case of Company B, considers as an important item to be inserted in the planning of lifecycle.

Company $\mathrm{C}$ is acting with greater advertising and promotional activities distributed in multiple vehicles and communication channels, such as print and digital media. Therefore, it has elements of rapid information and to reach the final consumer public as a way to give knowledge about a product that will hit the market already in the format modified by manufacturing industry.

Thereby, the advertising campaign (Figure 3) given below shows the approach to natural resource of largest use in jeanswear, which is water. It indicates that the product of this company decreases the amount of resource consumed by $40 \%$ and there are $75 \%$ optimized from dyeing. It also highlights the seal ISO 14001 of certification and the guarantee of innovation and sustainability in its production, but the main focus is water, which suggests that sustainability relies on this factor.

In accordance with the interview provided through the questionnaire, the addressed professional explains about the minimal use of natural resources, they point out that the information about sustainability are ways of driving the public, that advertising serves to demonstrate the company's ethics and attitudes to its collaborators.

The discourse on water in advertising demonstrates a media appeal, only a fragment of what the company values. For the general public can understand that only this line "Genius Denim" values sustainability, the campaign is highlight in the media, social networks and videos that are placed on the official website, but it is worth noting that there are other lines of products that do not have sustainable approach directed to a traditional market, but in the interview this is not covered and, in the website, it suggests that the technology that consumes less water is inserted in all product lines, so there is a mismatch between what is reported on the website and in the interview with what is published. 


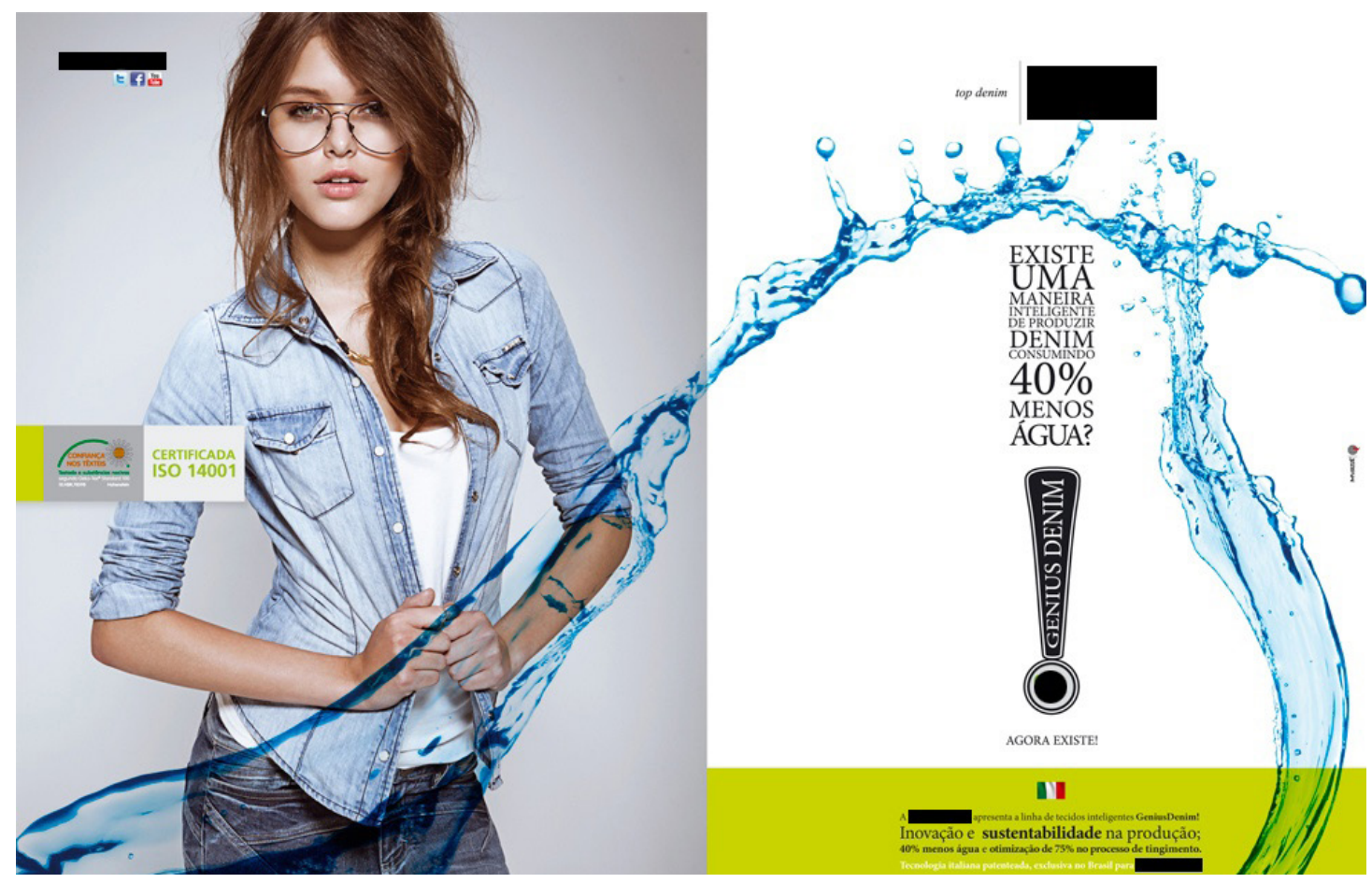

Figure $3^{8}$ : Company $C$ advertising campaign

Source: http://modaetica.com.br/. Accessed on: April 14, 2013

\section{FINAL CONSIDERATIONS}

The present study arose in order to observe and reflect on the approach to sustainability by fashion design, questioning the veracity of the speech expressed by companies. Thus, it can be stated that this study was able to achieve the goal, through interviews in which one could investigate how sustainable strategies are attended in order to designate a product as sustainable.

The research revealed that fashion companies with sustainable discourse gain the status of ecological before the general public. And, because it is an area that has gained more prominence in the media, it becomes a market advantage to demonstrate that a particular brand cares about the human being and his future on the planet.

However, it is observed that despite the message transmitted by some brands in their advertisements, these companies do not meet with their speech, because actually sustainability is highlighted when they should point the product as ecologic or ethic.

It is believed that the methodology has collaborated to recognize that the market for sustainable fashion is still walking in slow steps. After all, there are few industries with discourse and conduct truly sustainable, so that the research had trouble finding companies to the questionnaire application, which was treated with indifference by some.

It is concluded that there is still need of possible measures to be adopted for a sustainable fashion product, because it is a market still under construction.

Therefore, some pointers that can answer the questions reported in the research

\footnotetext{
${ }^{8}$ Is there a smart way of producing a denim consuming $40 \%$ less water? Now there is.
} 
are suggested, starting with some corporate information measures. Companies demonstrated they need methods so sustainability has the involvement of all employees, and for this process occur, the company should adopt forms that allow interaction with a common reason (in this case, sustainability). Greater knowledge and actions on sustainability, which can be supported by sustainable design, associated with design of information, would allow a more appropriate and effective implementation of sustainability and help in the exchange of information, and in formulating of products and systems, indeed, more sustainable.

\section{REFERENCES}

ABIT (2013) "Pesquisa Aponta que 46\% dos Brasileiros Usam Jeans Diariamente", Disponível em: http:// www.abit.org.br/Imprensa.aspx?Notld=388\#388|ND|C.

ABIT (2011) "Dados de Denim e Calça Jeans: Produção, Faturamento e Exportação", Disponível em: <http:// www.abit.org.br/site/navegacao.asp?id_menu=6\&id_sub=19\&idioma=PT>.

Agamben, G. (2009) O que é o Contemporâneo? E outros Ensaios, Santa Catarina: Editora Argos.

Baxter, M. (2011) Projeto de Produto: Guia Prático para o Design de Novos Produtos, São Paulo: Blucher.

Berlim, L. (2012) Moda e Sustentabilidade: Uma Reflexão Necessária, São Paulo: Estação das Letras.

Caldas, D. (2004) Observatório de Sinais: Teoria e Prática da Pesquisa de Tendências, Rio de Janeiro: Editora SENAC Rio.

De Carli, A. M. S. (2010) 'Moda no Terceiro Milênio: Novas Realidades, Novos Valores' in De Carli, A. M. S.; Manfredini, M. L. (eds.). (2010) Moda em Sintonia, Caxias do Sul: Educs, pp. 38-51.

Dougherty, B. (2011) Design Gráfico Sustentável, São Paulo: Edições Rosari.

Exame. (2011) "Greenpeace Alerta para Contaminação na Indústria Têxtil Mundial", [Online] Disponível em: <http://exame.abril.com.br/economia/meio-ambiente-e-energia/noticias/ greenpeace-alerta-para-contaminacao-na-industria-textil-mundial>.

Fletcher, K.; Grose, L. (2011) Moda Q Sustentabilidade: Design para mudança, São Paulo: Editora Senac São Paulo.

Frings, G. S. (2012) Moda: Do Conceito ao Consumidor, Porto Alegre: Bookman.

Kazazian, T. (2005) Haverá a Idade das Coisas Leves: Design e Desenvolvimento sustentável, São Paulo: Ed. Senac São Paulo.

“Le Tour du Monde d'un Jeans", (2013) [Online] Disponível em: http://www.dailymotion.com/video/ xbohoj_tunisie-le-tour-du-monde-d-un-jeans_people.

Lipovetsky, G. (1989) O Império do Efêmero, São Paulo: Companhia das Letras.

Lipovetsky, G; Charles, S. (2004) Os Tempos Hipermodernos, São Paulo: Editora Barcarolla.

Manzini, E.; Vezzoli, C. (2005) O Desenvolvimento de Produtos Sustentáveis: Os Requisitos Ambientais dos Produtos Industriais, São Paulo: Editora da Universidade de São Paulo.

Matharu, G. (2011) O que é Design de Moda?, Porto Alegre: Bookman. 
Mendes, F. D.; Lima, F. D. M. (2012) "Vestuário de Moda - Beneficiamento do Jeanswear e os Resíduos da Lavandaria", $8^{\circ}$ Colóquio de Moda, 2012. Anais, Rio de Janeiro.

Moura, M. (2008) "O Design Contemporâneo e suas Dobras (III)", dObra[s], v. 3: 32-35·[a]

Moura, M. (2008) “O Design Contemporâneo e suas Dobras (II)", dObra[s], v. 2:16-19.[b]

Moura, M. (2013) "Atualidades da Pesquisa em Design e Moda no Brasil”, dObra[s], v. 6, n 13: 24-35.

Oliveros, R. (2012) “Moda Sustentável só vai ser Possível em 100 anos”, diz estilista da Osklen. UOL, São Paulo, 19 jan. 2012. Disponível em: < http://estilo.uol.com.br/moda/ultimas-noticias/ redacao/2012/01/19/moda-sustentavel-so-vai-ser-possivel-em-100-anos-diz-estilista-da-osklen.htm >.

Parode, F. P., Remus, B. D. N., Visoná, P. (2010) 'Desafios da Moda em Tempos de Crise: Reflexões sobre Sustentabilidade e Consumo' in De Carli, A. M. S.; Manfredini, M. L. (eds.) (2010) Moda em Sintonia, Caxias do Sul: Educs, pp.65-79.

Peled, M. China Blue. (2013) [Online] Disponível em: http://vimeo.com/29896728.

Proctor, R. (2009) Diseño Ecológico: 1000 Ejemplos, Barcelona: Editorial Gustavo Gili.

Simmel, G. (1971) On Individuality and Social Forms, Chicago: Ed. Levine.

Tavares, M.; Arnt, R. (2013) “Velha, Azul, Desbotada... e Poluente”, [Online] Disponível em: http:// revistaplaneta.terra.com.br/secao/meio-ambiente/velha-azul-desbotada-e-poluente.

Thorpe, A. (2007) The Designer's Atlas of Sustainability, Washington: Island Press.

Tv Asa Branca.(2013) "Entenda o Processo de Fabricação de uma Calça Jeans", [Online] Disponível em: http://maisab.com.br/tvasabranca/blog/entenda-o-processo-de-fabricacao-de-uma-calca-jeans/.

Vezzoli, C. (2008) 'Cenário do Design para uma Moda Sustentável' in Pires, D. B. (2008) Design de Moda: Olhares Diversos, São Paulo: Estação das Letras e Cores, pp.197-205. 